\title{
The Changing Constitutional Framework of Church-State Relations in Europe
}

\section{Rainer Grote}

\begin{abstract}
Although the Christian religion has lost its once-dominant place in European societies as they have taken on a more secular, religiously diverse character in the post-World War II era, the constitutional principles and rules governing the relationship between state and church have remained remarkably stable in most parts of non-Communist Europe. They can be grouped into three main categories, depending on the form and degree of cooperation or separation they provide for in the relationship between the established Church(es) and the state. By contrast, the task of accommodating the new religious groups including Muslims which are an important feature of the increasing religious diversity of European societies within the existing constitutional settlements on the relationship between the state and religion has largely been left to the legislature and the courts. This has allowed new meta-norms to penetrate the constitutional space of the European states, particularly the guarantees in the European Convention of Human Rights on religious liberty in its individual as well as collective dimensions and the principle of non-discrimination on religious grounds.
\end{abstract}

\section{Introduction: The centrality of the state-church relationship to the constitutional systems of European states}

The relationship between the state and religious groups and organizations has been central to the emergence of the constitutional state in modern Europe. It has rightly been claimed that the "constitutional connections between church and state are part of Europe's history, whether they are retained or rejected", and that the existence of a constitutional connection between church and state is a "common thread within West Europe". ${ }^{1}$

1 Grace Davie, Europe: The Exceptional Case. Parameters of Faith in the Modern World. Darton \& Longman \&Todd Ltd., 2002: 2 and 12. 
While in some countries this relationship has been a highly conflictual one during important periods of history, as in Germany in the Reformation era or in France following the Revolution, in other countries its legal accommodation and institutionalization has taken place without major disruption. As the path to modern statehood has not been uniform, the regulation of the central aspects of the relationship between state and church in the constitutional law of the various European countries has not followed a uniform model, either. On the contrary, it appears as if this is one of the areas of constitutional regulation which has been more deeply marked by the particularities of the constitutional history of the respective country than other areas, e.g. fundamental rights. Although the Christian religion has lost its once-dominant place in European societies as they gradually took on a more secular, religiously more diverse character in the postWorld War II era, the central principles and rules concerning the constitutional relationship between state and church have remained remarkably stable in most parts of non-Communist Europe (see Section 2), if only because a consensus in the question whether and how to reform the existing rules proved difficult to achieve (Section 3). This has meant that constitutional practice has increasingly turned to the interpretation and application of the fundamental right to freedom of religion in its individual and as well as collective dimension to find adequate solutions to the new, pressing questions concerning the proper role of the church in public life of secular liberal democracies (Section 4). As a result, the struggle on the proper role of religion in public life in Europe today concerns less the individual right to religious freedom than the legal position of the different denominations, especially of the more recently arrived and those at odds with the traditional parameters shaped by the long period of dominance of Christian denominations (Section 5) The discussion on how the new religious diversity can be accommodated in constitutional and legal terms is thus far from over (Section 6).

\section{Regulation of the state-church relationship in European constitutions}

The regulation of the state-church relationship has historically been central to the constitutional and political identity of European states. This is still reflected in a number of European constitutions which assign a privileged 
role to the Christian religion in its Catholic, Protestant or Orthodox variety. ${ }^{2}$

The Protestant religion has traditionally been accorded a prominent place in the constitutional arrangements of the Northern European countries, particularly in the Scandinavian countries and the United Kingdom. Article 4 of the Danish Constitution of 1953 declares that the Evangelical Lutheran Church shall be the Established Church of Denmark, and as such shall be supported by the State. The King as Head of State shall be a member of the Evangelical Lutheran Church (Article 6). According to Article 66, the Constitution of the Evangelical-Lutheran Church of Denmark shall be regulated by an act of Parliament. However, the promise of a synodical constitution for the Church of Denmark which would give it autonomy to freely decide on all ecclesiastical matters and to establish a central church council that could speak on behalf of the church was never honored, with the consequence that still today the administration of church matters is in the hands of the government, through the Ministry of Ecclesiastical Affairs. ${ }^{3}$ As in Denmark, no freedom of religion exists for members of Sweden's royal family. According to Article 4 of the Swedish Act of Succession, "the King shall always profess the pure evangelical faith, as adopted and explained in the unaltered Confession of Augsburg and in the Resolution of the Uppsala meeting of the year 1593, princes and princesses of the Royal House shall be brought up in that same faith and within the Realm. Any member of the Royal Family not professing this faith shall be excluded from all rights of succession." Article 4 of the Norwegian Constitution of 1814 is equally categorical: "The King shall at all times profess the Evangelical-Lutheran religion."

In the United Kingdom, the monarch is by constitutional statute the Act of Settlement of 1701 - required to be "in communion with the Church of England", of which he/she serves as Supreme Governor since the adoption of Act of Supremacy of 1534. At the same time, the monarch is also a member of a reformed, Presbyterian church north of the English border, in Scotland. ${ }^{4}$ The business of the Church of England

2 Gerhard Robbers, "State and Church in the European Union." In: State and Church in the European Union, $3^{\text {rd }}$ edition, edited by Gerhard Robbers. Nomos, 2019: 679; Russell Sandberg and Norman Doe, "Church-State Relations in Europe." Religion Compass 1.5, 2007: 561 and 563.

3 Niels Valdemar Vinding, "State and Church in Denmark." In: State and Church in the European Union, $3^{\text {rd }}$ edition, edited by Gerhard Robbers. Nomos, 2019: 90.

4 David McClean, "State and Church in the United Kingdom." In: State and Church in the European Union, $3^{\text {rd }}$ edition, edited by Gerhard Robbers. Nomos, 2019: 657. 
is closely bound up with the business of the State. Many senior church appointments involve Crown patronage, though this power is in practice exercised by government officials acting in close consultation with the church authorities, thus ensuring that the appointments are not subject to political influence. ${ }^{5}$ Two archbishops and 24 diocesan bishops of the Church of England are members of the House of Lords. By convention, these spiritual peers do not speak or vote on purely political issues. While this arrangement has been criticized by some, it has been defended by others not only on the basis of tradition and the close links between the established Church of England and the state, but also with regard to the substantial contribution the spiritual peers, who do not owe allegiance to any political party, make to debate on often sensitive moral and social issues, such as housing, divorce, abortion, embryology, homosexuality, and human fertilization. ${ }^{6}$

An even stronger place is accorded to the Eastern Orthodox Church in the Greek Constitution of 1975. Article 3 refers to the Greek Orthodox Church as the "prevailing" religion in Greece, a terminology which is not meant to grant the Orthodox Church superiority over all other religious communities but to reflect the fact that the vast majority of Greeks (over 90\%) are baptized Orthodox Christians. ${ }^{7}$ Article 3 represents a constitutional acknowledgement of the unique role the Orthodox clergy and the Orthodox Church have played in preserving Greek language, culture and identity during the four centuries of Turkish rule. ${ }^{8}$ The freedom of religion for the believers of other faiths is guaranteed by Article 113 which declares the freedom of religious conscience to be inviolable. However, the constitutional guarantee of the freedom of religion is framed in somewhat restrictive terms. The practice of rites of worship extends only to "known religions' (i.e. those which do not have secret teachings or dogmas), and it may not offend the public order or the good usages, a restriction which is more likely to be applied to Muslim, Catholic, Protestant or Jewish rites in an overwhelmingly Orthodox environment than to the practices of the dominant Orthodox majority religion.

5 McClean, "State and Church in the United Kingdom": 664.

6 Hilaire Barnett, Constitutional and Administrative Law, $13^{\text {th }}$ edition. Routledge, 2020: 387.

7 Lina Papadopoulou, "State and Church in Greece." In: State and Church in the European Union, $3^{\text {rd }}$ edition, edited by Gerhard Robbers. Nomos, 2019: 171.

8 See Philipos K. Spyropoulos and Theodore P. Fortsakis, Constitutional Law in Greece, $3^{\text {rd }}$ edition. Kluwer Law International, 2017: para. 721, who note that Greece has the greatest degree of religious homogeneity of any European country. 
While they go not so far as to recognize a particular religious community as "state", "national", "established", or "folk" church, a number of other European constitutions still acknowledge certain Christian communities as privileged cooperation partners. This is the case frequently in countries whose religious culture has been deeply marked by a centuries-long close affiliation with the Catholic Church, like Spain, Italy, or Austria. While Article 16 of the Spanish Constitution of 1978 declares that there shall be no state religion, it also exhorts the public authorities to take the religious beliefs in Spanish society (which continues to be heavily dominated by Catholics) $)^{9}$ into account and shall in consequence maintain appropriate co-operation with the Catholic Church and the other religious confessions. Similarly, a distinctive feature of the Italian Constitution of 1947 is the privileged status it accords the Roman Catholic Church. While the principles of freedom and equality of all religious confessions are explicitly enshrined in Article 8, the Constitution recognizes the special position of the Roman Catholic Church by declaring in Article 7 that, like the state, the Catholic Church is within its own order not only independent, but sovereign. Although the wording of Article 7 does not expressly confer upon Roman Catholicism the status of "official" or "state religion", a very similar result has been achieved by incorporation of the Lateran Pacts by virtue of paragraph 2 of the same provision. The Lateran Pacts ${ }^{10}$ ended the church-state conflict caused by the annexation of the Papal States and Rome during the unification of Italy and the establishment of a liberal national state. In the Conciliation Treaty, Italy recognized the sovereign authority of the Holy See over the Vatican City ${ }^{11}$ and reaffirmed the principle that "the Catholic Apostolic Roman religion is the only State religion". ${ }^{12}$ At the same time the Concordat between the Catholic Church and the Italian state provided for religious education in state primary and secondary schools.

9 A survey published by the Centro de Investigaciones Sociólogicas in October 2017 counted $67.6 \%$ of the population as Catholics and 3.1\% as followers of another religion, with the rest being non-believers or atheists, see Ibán C. Ibán, "State and Church in Spain." In: State and Church in the European Union, $3^{\text {rd }}$ edition, edited by Gerhard Robbers. Nomos, 2019: 195.

10 The Lateran Pacts consist of a treaty of conciliation, a financial convention and the Concordat between the Catholic Church and the Italian state. The financial convention is sometimes presented not as a separate agreement but as an annex to the Conciliation Treaty.

11 Conciliation Treaty, art. 3.

12 Conciliation Treaty, art. 1. 
In Austria the state and the religious communities are partners on an equal footing, each acknowledging the independence and autonomy of the other. The principles governing the relationship between state and church have been laid down in a number of different enactments. The status of the Catholic Church is specified above all by the Concordat of 1933 and a number of further laws that regulate the relationship between the Austrian state and the Holy See in various areas. Article 5 of the Concordat guarantees the continued existence of the Faculties of Catholic Theology at the Universities of Vienna, Graz, Innsbruck and Salzburg. The Catholic Church has also made use of the legislation ending the state monopoly in University education to establish a Theological Private University in Linz. ${ }^{13}$

Somewhat different is the situation in Germany, the country in which the Reformation originated. Its constitutional law thus has had to accommodate the Catholic as well as the Protestant religious communities which have both a deeply rooted and strong presence in the country. This need is reflected in the constitutional rules on the relationship between the state and religious groups in Article 140 of the Basic Law which incorporates the historical compromise reached on this thorny issue in the Weimar Constitution. According to the relevant article of the Weimar Constitution, "religious societies shall remain corporations under public law insofar as they have enjoyed that status in the past. Other religious societies shall be granted the same status upon application, if their constitution and the number of their members give assurance of their permanency." The article's primary purpose was to spare the traditional churches, the Catholic Church and the Protestant churches, the status of mere private associations, the latter often being organized as "state churches" at the level of the principalities which had historically composed the German Empire. Given their important functions and relevance at the time, such a private status of the two main Christian communities was widely seen as inadequate by the drafters of the Weimar Constitution. The relevant provisions of the Weimar Constitution carried over into the Constitution of the Federal Republic of Germany therefore recognize the traditional importance of the main Christian denominations and allow for close coop-

13 Richard Potz, "State and Church in Austria." In: State and Church in the European Union, $3^{\text {rd }}$ edition, edited by Gerhard Robbers. Nomos, 2019: 448, 450. 
eration in matters such as religious instruction in the public school system, the church tax and military chaplaincy. ${ }^{14}$

At the other hand of the spectrum, French constitutional law codifies the result of the protracted historical struggle for full emancipation of the state from the overbearing influence of the Catholic church which had been initiated by the Jacobins in the French Revolution at the end of the 18th century and brought to a - from their point of view - successful conclusion by the radical Republicans of the Third Republic at the beginning of the 20th century. The secular character of the French Republic is now enshrined in Article 1 of the 1958 Constitution: "La France est une République indivisible, laïque...". Laicité implies the strict neutrality of the Republic in all religious matters. The Republic shall respect all beliefs but not identify itself with any of them, nor shall it remunerate persons of any faith. ${ }^{15}$ The most important statutory expression of the principle of secularity, or laicité, in the French tradition, is the Act on the Separation of the State and the Churches of December 1905. The Law famously declares that the Republic neither recognizes, nor salaries, nor subsidizes any religion. In particular, the principle imposes a strict duty of religious neutrality on all public services, including the educational services, in the exercise of their functions.

\section{Perseverance of constitutional regulations of the state-church relationship}

As described above, the integration of religion into the state, in one way or the other, was central to the emergence of the modern "secular" European state, and was not achieved without sometimes violent conflict. European states have therefore been reluctant to touch the constitutional settlement on state and religion, even if it does no longer correspond to the needs of fast-changing, multi-religious and often increasingly secular societies. Constitutional reforms addressing the basic relations between state and religion have therefore been slow and piecemeal (England, Norway, Sweden) whereas in other countries change has been limited to statutory legislation and jurisprudential practice (Italy, France).

14 Gerhard Robbers, "State and Church in Germany." In: State and Church in the European Union, $3^{\text {rd }}$ edition, edited by Gerhard Robbers. Nomos, 2019: 110.

15 On the interpretation of the principle of laicité by the French Conseil constitutionnel see CC 2012-297, QPC, February 21, 2013. 
In England, it was only in 2013 that the Succession to the Crown Act 2013 ended the disqualification of a person who marries a Roman Catholic from the line of succession to the throne. In Norway, reforms adopted on the occasion of the bicentenary of the Norwegian Grunnloven have been more comprehensive. The provision that the Evangelical Lutheran Church shall be the official religion of the state was removed from the Norwegian Constitution by the Constitutional Reform of 2012 and replaced by a general commitment to Norway's "Christian and humanist heritage" (Grl. $\$ 2$ ). Similarly, the obligation of Norwegians professing the EvangelicalLutheran religion to raise their children in the same faith has disappeared from the constitutional text. Though the Church of Norway, an Evangelical-Lutheran Church, will remain the established Church of Norway and will as such be supported by the State, this support is no longer an exclusive privilege of the Evangelical-Lutheran Church. In addition to guaranteeing the freedom of religion to all inhabitants $₫ 16$ now provides for public support of all religious and belief communities "on equal terms." The special links between the highest representatives of the state and the Evangelical-Lutheran religion have been severed. $\$ 4$ still requires the King to profess the Evangelical-Lutheran religion, but his constitutional duty "to uphold and protect" that religion has been abolished. The King has lost the competence to appoint and dismiss the holders of ecclesiastical offices which he exercised - in consultation with the government - until the 2012 reforms. Moreover, the requirement in $\mathbb{1} 12$ that more than half of the members of the Council of State, i.e. of the Norwegian Government, must profess the Evangelical-Lutheran religion was also dropped.

Similarly, in Sweden, the Lutheran Church remained the state church until 2000 when it was finally disestablished. However, the Swedish monarch must still profess the "pure evangelical faith", although he/she is now allowed to marry a non-evangelical partner.

In Italy, the privileged status accorded to the Catholic Church under the 1947 Constitution became more controversial over the years, and negotiations to modify the relations between state and church were initiated in the late 1960s. After seventeen years of negotiation, a new concordat was concluded in 1984 which ended the status of Roman Catholicism as the established state religion and eliminated many of the other privileges of the Church, such as compulsory religious education in schools and exemptions from civil law jurisdiction granted to priests, while confirming the freedom of the Church to pursue its charitable, educational and pas- 
toral endeavors. ${ }^{16} \mathrm{~A}$ number of other issues, such as regulations applied to ecclesiastical property as well as various financial matters, were left to a special commission which was able to reach an agreement in a protocol signed in November 1984. In the protocol, the Vatican and the Italian Government agreed to cancel state subsidies for clerical salaries, although generous tax breaks were provided to taxpayers in return for contributions to the bishops' funds from which the salaries were paid. In addition, churches and seminaries open to the public would receive tax benefits, and the state promised to support the Church in the maintenance of religious buildings and works of art open to the public. ${ }^{17}$

In France, the principle of laicité has come increasingly under pressure in the public education system since the 1990s when pupils and students began to openly wear symbols of their religious affiliation like headscarves or refused to attend certain classes, like biology or physical education, which they considered to be at odds with their religious beliefs. After much argument and litigation, including before the Conseil d'Etat, the French Parliament finally enacted the Act on Secularity and Conspicuous Religious Symbols in Schools. ${ }^{18}$ It bans the wearing of conspicuous religious symbols in French public primary and secondary schools (but not in universities). The law - which was not challenged before the Constitutional Council (Conseil constitutionnel) - can be seen as a reaffirmation of the principle of laicité in the public education system. However, it leaves some room for compromise in daily school life as it does not prohibit any religious garb or symbol but only those of a conspicuous character.

\section{The shift from an institutional to a rights-based approach: The growing influence of human rights law}

The traditional focus on the institutional relationship between state and church is increasingly sidelined in many contemporary European societies by the concept of religion as a basic freedom. As such it has been incorporated in all contemporary European constitutions. In addition, freedom of religion has been included in the European Convention of Human Rights

16 Maria Elisabetta DeFranciscis, Italy and the Vatican: The 1984 Concordat between Church and State. Verlag Peter Lang, 1989 : 142-146.

17 DeFranciscis, Italy and the Vatican: 146-149.

18 Loi $n^{\circ}$ 2004-228 du 15 mars 2004 encadrant, en application du principe de laïcité, le port de signes ou de tenues manifestant une appartenance religieuse dans les écoles, collèges et lycées publics, Journal officiel 65 of March 17, 2004 : 5190. 
(ECHR, art. 9) and the Charter on Fundamental Rights of the European Union (art. 10). At the same time, Article 17 of the Treaty on the Functioning of the European Union contains a guarantee of non-interference by the EU with the regulatory frameworks that have been established in the Member States for state-church relations: "The Union respects and does not prejudice the status under national law of churches and religious associations or communities in the Member States."

Article 9 of the European Convention on Human Rights, in particular, has played an increasingly important role in the regulation of statechurch relations in the Member States of the Council of Europe. While the Convention enjoys constitutional rank only in a few Member States, Article 9 influences the interpretation of the corresponding constitutional liberties also in those countries which have incorporated the ECHR into the domestic legal system by way of ordinary statute, as all states have an international obligation to give effect to freedom of religion as defined by ECHR (art. 9), and can be taken before the European Court of Human Rights if the domestic authorities, including the domestic courts, fail to do so. While the focus of Article 9 is on the freedom of the individual to choose, change and manifest his/her religion in public or private, ${ }^{19}$ it also expressly covers the collective dimension of religious liberty, i.e. the right to practice the religion of one's choice "either alone or in community with others." This does not by itself call into question the various types of constitutional regulation of state-church relations as they have developed in the Member States Europe since the Reformation. The European Court of Human Rights has expressly endorsed the position of the former European Commission on Human Rights that a State Church system cannot by itself be considered as a violation of Article 9 of the Convention as such a system already existed in several Member States when the Convention was drafted and when they became parties to it. ${ }^{20}$

However, the turn to an individualist understanding of religious freedom is supported at the level of the individual Member States by a weakening of the traditional link between collective (national) identity and a specific religious affiliation, a trend which tends to delegitimize the established privileged legal relationships between the state and the traditional Christian churches. The European Human Rights Commission acknowledged as much in its already cited opinion in the Darby case. Here it noted, that while Member States remain free to maintain an existing State

20 Darby v. Sweden A 187 (1990), Commission Report: para. 45. 
Church system, they must, in order to satisfy the requirements of Article 9 of the $E C H R$, include specific safeguards for the individual's freedom of religion. In particular, no one may be forced to enter, or prohibited from leaving, a state church. ${ }^{21}$ The lack of such safeguards has given rise to several successful complaints against Greece, which in Article 13(2) of the Constitution explicitly prohibits proselytism, a provision which is likely to work to the disadvantage of the minority religious groups rather than to the detriment of the Orthodox Church in a country where 90\% of the total population already are Orthodox Christians. As a matter of fact, the initial version of the provision was confined to the protection only of the Orthodox Church. ${ }^{22}$ The amended provision may no longer be discriminatory within the meaning of ECHR (art. 14), still its broad interpretation by the Greek courts to the detriment of minority religious groups has led to several rulings against Greece by the European Court of Human Rights for violation of $E C H R$ (art. 9), which in the interpretation of the Court in principle also includes the right to convince others to join one's religious community. ${ }^{23}$

The jurisprudence concerning the application of Article 13(2) of the Greek Constitution also has implications for the interpretation of the provision in Article 3 that the Greek Orthodox Church of Christ is the prevailing religion in Greece. Some Greek authors have understood the reference to the "prevailing" status of the Orthodox religion as meaning that the Greek Orthodox faith is the official religion of the Greek state, that the church which embodies this faith has its own legal status, and that it is treated by the state with special concern and in a favorable manner which is not extended to other faiths and religions. ${ }^{24}$ However, this view does no longer seem to be accepted by contemporary Greek doctrine which stresses that, especially with regard to the official status of the Orthodox religion and the preferential treatment of the Greek Orthodox Church by the state such interpretation is hardly consistent with either the constitutional principle of (religious) equality or the protection of religious freedom in

21 See n. 20.

22 Spyropoulos and Fortsakis, Constitutional Law in Greece: para. 715.

23 Kokkinakis v. Greece A 260-A (1993) (concerning proselytizing activities by Jehova's Witnesses); Larissis and Others $v$. Greece 1998-I (concerning proselytizing activities by members of the Pentecostal Church in the Greek air force).

24 Charalampos Papasthatis, "State and Church in Greece." In: State and Church in the European Union, $1^{\text {st }}$, edited by Gerhard Robbers. Nomos, 2005: 117. 
combination with the prohibition of discrimination on religious grounds in ECHR (arts. 9 and 14). ${ }^{25}$

\section{The new challenge: Genuine religious equality in religiously heterogeneous societies}

Some time ago a leading Italian scholar observed that while the Italian legal order is in line with the main provisions of international law and the principles contained in most of the constitutions of the other Western countries as far as the individual rights to religious freedom and equality are concerned, the picture grows more complex when one looks at the legal position of the different religious denominations active in Italian society. In this domain, he argued, the Italian system of concordats and agreements discriminates in some ways among the various denominations, and this, in turn, may have an impact on the legal position of individual members of the various denominations. ${ }^{26} \mathrm{He}$ went on to characterize the law governing the relationship between the Italian state and the different religious communities as a three-tiered system in which the most prominent position is held by the Catholic Church, on the basis of the preferential treatment secured by the church in the agreements of 1984 (see III. above) and numerous other regulations in ordinary law. The religious communities that have come to an agreement with the state occupy an intermediate position. This category includes both groups which have existed in Italy for a long time, like the Jews and the Protestants, and more recent groups which have no characteristics incompatible with Italian law. They are guaranteed a position equivalent, if not equal, to that of the Catholic Church. The lowest tier is formed by groups who have only recently settled in Italy and whose doctrines and practices are perceived to be in conflict with public order, although some of them, like Muslims and Jehovah's Witnesses, have a significant number of adherents. These groups are regulated by Law 1159 of 1929 and the general law on associations. ${ }^{27}$ The religious groups in the lowest tier are excluded from some important

25 Papadopoulou, "State and Church in Greece": 175.

26 Silvio Ferrari, "The Emerging Pattern of Church and State in Western Europe: The Italian Model.” Brigham Young University Law Review 1995: 421 and 430.

27 Law 1159 of 1929 establishes that religious groups registered in Italy will benefit from the same privileges as groups with charitable and educational purposes, including important tax privileges, see Ferrari, “The Italian Model”: 433. 
privileges which are granted to those churches and religious communities that have the benefit of a concordat or agreement. ${ }^{28}$

As the author, Silvio Ferrari, also notes, the three-tiered system developed as a result of Italian history and culture, but is hardly unique to Italy. Other European countries use similar multi-level classifications. ${ }^{29}$ In Austria, the way in which followers of a denomination can obtain legal recognition as a religious association is regulated by the Recognition Act (AnerkennungG) 1874. According to Section 1 of the Act, recognition as a religious association will be granted to the followers of a previously legally unrecognized denomination under the condition that religious teaching, service, statutes and chosen names do not contain anything illegal or morally offensive, and that at least one cult community is created in accordance with the requirements of the Recognition Act. However, in 1998 an additional condition was added - that the denomination represents at least $2 \%$ of the Austrian population - which has significantly limited the number of suitable candidates for recognition. ${ }^{30}$ In addition, the law on the religious activities of the "historically recognized" churches and religious societies is not found in the Recognition Act, but is developed by way of special laws. This tends to favor the established Christian churches, and namely the Catholic Church. For the Catholic Church, the special law is to be found in the Concordat 1933 and additional and complementary treaties which, among other things, give the Catholic Church a guarantee that it may make laws, decrees and orders within its own field of competence without hindrance, and that the institutions of the Catholic Church with legal personality according to Canon Law also enjoy public law personality in the sphere of State law. ${ }^{31}$

The situation is similar in Germany, with the difference that the "historical" Protestant Churches in Germany enjoy a position not only equivalent, but equal to that of the Catholic Church. These treaties and agreements supplement the rules laid down in Article 140 of the Basic Law with reference to the Weimar Constitution (art. 137), according to which every religious community can receive the status of a public law corporation provided it can prove through its bye-laws and the number of its members that it is a permanent community. Other religious communities receive their legal capacity as a result of civil law. ${ }^{32}$ However, important parts of

28 Ferrari, “The Italian Model”: 430.

29 Ferrari, "The Italian Model": 430.

30 Potz, "State and Church in Austria": 440.

31 Potz, "State and Church in Austria": 441.

32 Robbers, "State and Church in Germany": 113. 
the law governing the activities of religious communities in Germany are found in the many concordats and treaties which the Federal Republic of Germany and the various Länder have established with the Churches in Germany. In relation to the Catholic Church, the Reichskonkordat of 1933 is the essential basis, which is recognized as a treaty under international law. Church-State treaties with the Evangelical Church are sui generis but are treated as being in a category similar to that of international treaties. The subject matter of the concordats and treaties concern the cooperation between the State and the Churches, the guarantees and arrangements for religious education in public schools, the theological faculties, the military chaplains and the position of the churches in the public sphere, such as the financing of religious parishes. ${ }^{33}$ While treaties or agreements also exist with a whole range of smaller religious congregations, including Jewish as well as some Muslim communities, such communities - apart from the Jewish communities which for historical reasons occupy a special place in German public life - will often have less clout than the traditional Catholic and Protestant Churches to extract significant concessions from the State through these agreements.

Even in countries which have implemented a system of separation which was initially directed against the powerful position of a traditional religion by subjecting all religious communities equally to private law regulation, as in France, recent practice has shown that the public authorities are similarly likely to struggle with the accommodation of unsettling aspects of the new religious diversity in society. Even in such a system ordinary legislation may be couched in terms which, while formally applying to all citizens, are directed against the religious practices of some groups and not others. This had been demonstrated by the controversy on the Law on the ban of face veils from the public sphere in France, which went right up to the European Court of Human Rights. ${ }^{34}$

\section{Conclusion: The elusive goal of religious equality}

This incomplete survey has shown that the constitutional and legal systems of the European states retain a regulatory framework for the relation

33 Robbers, "State and Church in Germany": 111.

34 SAS v. France (GC), Reports 2014-III, 291. On the ruling see Christoph Grabenwarter, "Das Urteil des EGMR zum französischen Verbot der Burka." In: Islam, Recht und Diversität, edited by Stephan Hinghofer-Szalkay and Herbert Kalb. Verlag Österreich, 2018: 523. 
between the state and religious groups which have been marked by the central place the Christian religion has occupied in these countries for many centuries. Traditionally, these systems have been grouped in three main categories: the State Church systems (which are mainly found in Northern Europe but also include Greece), separation systems (for which France provides the most important example), and hybrid or cooperation systems which combine the formal separation of state and church with the recognition of a multitude of common tasks that link state and church activity (a model which has often been embraced by countries with a strong Catholic tradition and population). ${ }^{35}$ In recent times, however, these distinctions have increasingly been criticized as having more to do with historical theory than sociological reality. ${ }^{36}$ On the one hand, the systems recognizing a religious affiliation as state religion or official religion have often made considerable efforts to disentangle State business from Church business in recent decades, as in England, Norway or Sweden. On the other hand, the formal separation of State and Church often hides, particularly in Catholic states, a clear legal favoring of the Roman Catholic Church, on the basis of a Concordat between State and Catholic Church (as in Italy or Austria) or even without one (Belgium). ${ }^{37}$

Despite the increasing religious diversity of many European societies, the formal changes to the existing constitutional regulations of the statechurch relationship have been slow to arrive and mostly been limited in scope. This is due to the strength of tradition and the relatively high barriers to constitutional amendments, but also to the lack of consensus on the principles and rules which should govern the relationship between state and the religious communities, old as well as new, in the 21 st century, in the light of increasing religious diversity and a more individualist understanding and practice of religion in many segments of contemporary society.

As a consequence, the task of defining the new "rules of the game" has mostly been left to legislation and court practice. This has allowed new meta-norms to penetrate the constitutional space of the European states. In the field of religion, these norms are primarily to be found in international and human rights law. Particularly the guarantees in the $E C H R$ have started to exercise a transforming influence on Member States'

35 Robbers, "State and Church in the European Union": 679.

36 Sandberg and Doe, "Church-State Relations in Europe": 565.

37 Sandberg and Doe, "Church-State Relations in Europe": 568. 
constitutional and legal systems. ${ }^{38}$ While formally respectful of the existing institutional arrangements in the State-church relations of Member States, the European Court of Human Rights' jurisprudence has made it more difficult to maintain existing public preferences in favor of established religious communities and to burden non-traditional communities with excessive restrictions and regulatory requirements. This can be seen as part of a gradual process creating the legal conditions for religiously more open societies which is far from completion. It is all the more difficult as the religious freedom of the various faiths and their followers also has to be balanced with the fundamental liberties of the important and growing part of the population which do not embrace any religious faith at all.

38 Potz, "State and Church in Austria": 437, concerning the Austrian case. 